
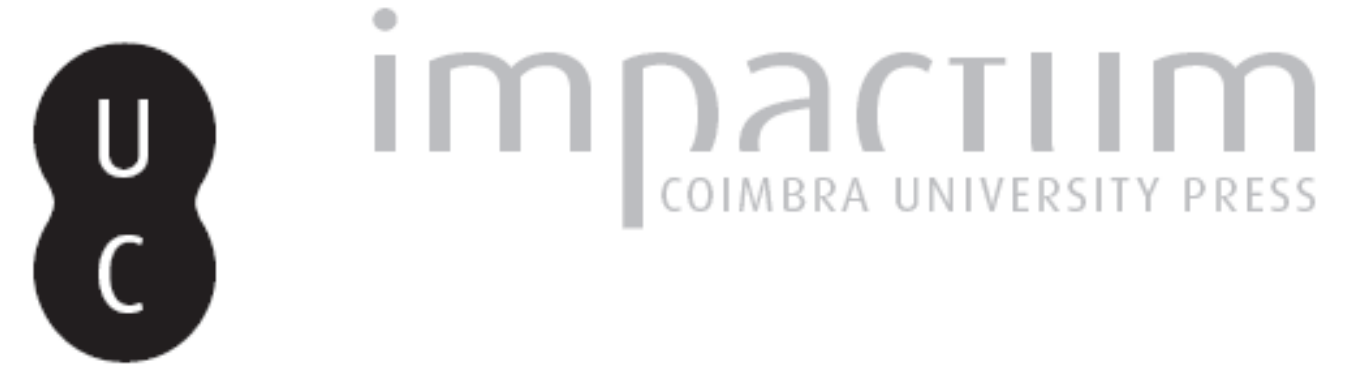

Immanuel Kant: ensaio sobre as doenças da cabeça de 1764

Autor(es): $\quad$ Panarra, Pedro Miguel, trad.

Publicado por: Faculdade de Letras da Universidade de Coimbra, Instituto de Estudos Filosóficos

URL

persistente:

URI:http://hdl.handle.net/10316.2/33344

DOI:

DOI:http://dx.doi.org/10.14195/0872-0851_37_10

Accessed : $\quad$ 26-Apr-2023 15:05:44

A navegação consulta e descarregamento dos títulos inseridos nas Bibliotecas Digitais UC Digitalis, UC Pombalina e UC Impactum, pressupõem a aceitação plena e sem reservas dos Termos e Condições de Uso destas Bibliotecas Digitais, disponíveis em https://digitalis.uc.pt/pt-pt/termos.

Conforme exposto nos referidos Termos e Condições de Uso, o descarregamento de títulos de acesso restrito requer uma licença válida de autorização devendo o utilizador aceder ao(s) documento(s) a partir de um endereço de IP da instituição detentora da supramencionada licença.

Ao utilizador é apenas permitido o descarregamento para uso pessoal, pelo que o emprego do(s) título(s) descarregado(s) para outro fim, designadamente comercial, carece de autorização do respetivo autor ou editor da obra.

Na medida em que todas as obras da UC Digitalis se encontram protegidas pelo Código do Direito de Autor e Direitos Conexos e demais legislação aplicável, toda a cópia, parcial ou total, deste documento, nos casos em que é legalmente admitida, deverá conter ou fazer-se acompanhar por este aviso.

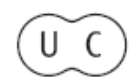




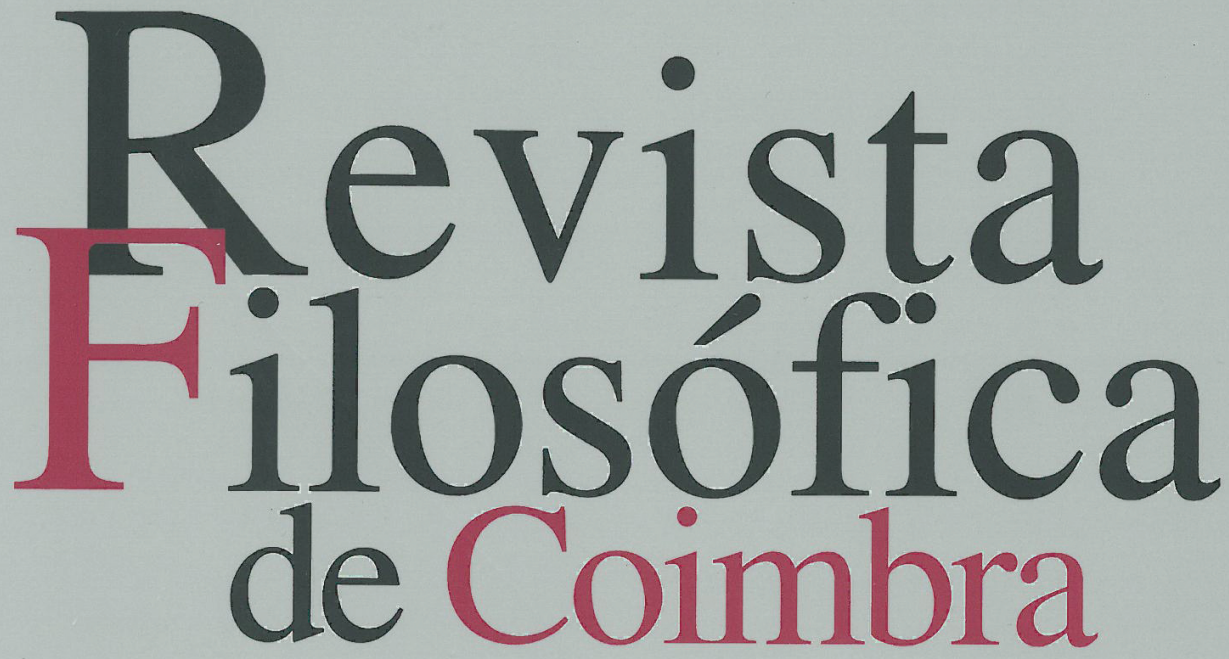

vol.19|n. $.37 \mid 2010$

Maria Luísa Portocarrero Mário Santiago de Carvalho Alexandre Franco de Sá Luís António Umbelino Luís G. Soto José Filipe Silva Joaquim Braga Maria da Conceição Camps Pedro Miguel Panarra Immanuel Kant 


\section{IMMANUEL KANT ENSAIO SOBRE AS DOENÇAS DA CABEÇA DE 1764}

Tradução e introdução de PEDRO MIGUEL PANARRA*

\section{1 - Introdução}

I. O tema da loucura no pensamento de Kant: Analogia com o pensamento metafísico

Apresentação e contextualização do escrito de Kant.

O presente artigo pretende introduzir de uma forma breve o escrito pré-crítico de Immanuel Kant, Ensaio sobre as doenças da cabeça, publicado em 1764, cuja tradução é apresentada neste mesmo número da Revista Filosófica de Coimbra. Vamos procurar fazê-lo através de um procedimento com dois momentos lógicos distintos: num primeiro momento descrevendo as circunstâncias, as preocupações e o contexto teórico e social da sua aparição; num segundo momento avançando um conjunto de esclarecimentos que permitam identificar certos elementos fundamentais da sua estrutura interna, de modo a poder esboçar uma interpretação a seu respeito.

A introdução que apresentamos não pretende ser um estudo sistemático e minucioso de o Ensaio, e menos ainda uma interpretação exaustiva do seu tema central, o estudo da loucura, fito que careceria de uma comparação sistemática com os capítulos paralelos da Antropologia de um ponto de vista pragmático de 1798, nos quais se desenvolve um processo de apresentação das perturbações psicopatológicas, paralelo ao primeiro e que com ele mantém semelhanças, quer no que diz respeito à aparência mais imediata quer à estrutura interna da taxonomia. Na verdade, este é o único escrito de Kant, em que o tema da loucura é considerado de forma

* Investigador do Thomas Institut, Univ. de Colónia. 
autónoma. Todas as outras análises kantianas do tema, são apenas partes de livros, fragmentos de outros escritos ou reflexões manuscritas disponíveis no espólio. Além do mais, esta reflexão pode ser associada a outros temas e ter por isso um carácter subsidiário ou, pelo contrário, estar em primeiro plano e constituir o tema principal, como sucede neste caso. A importância de o Ensaio sobre as doenças da cabeça, deve-se em parte à circunstância de ser nele que se apresenta pela primeira vez este tema e que, em simultâneo, se começa a forjar também um novo campo semântico que será decisivo para o desenvolvimento do pensamento transcendental. Por sua vez a elaboração desse campo semântico permite a Kant iniciar a apresentação de uma perspectiva sobre a loucura com aspectos inovadores bem como elaborar a linguagem que permite pensar a ilusão e a propensão para o excesso que são intrínsecos ao uso teórico da razão humana, movimento que constituirá o ponto de partida da elaboração da dialéctica transcendental.

II. Apresentação histórica da aparição do escrito Ensaio sobre as doenças da cabeça.

O Ensaio sobre as doenças da cabeça foi publicado por Kant em Königsberg, em cinco números da revista, Königsbergischen Gelehrten und politischen Zeitungen, tendo tido início no mês de Fevereiro de 1764. Só alguns anos mais tarde o texto foi editado em livro. Esta revista era editada e foi fundada pelo filósofo Johann Georg Hamman, amigo e antigo aluno de Kant, que nela colaborou amiúde. A sua actividade de articulista e comentador de assuntos da actualidade é, aliás, pouco referida e foi durante muitos anos uma componente importante da atitude viva e calorosamente sociável de Kant, que participou em vários concursos de natureza científica ou filosófica, assim como escreveu com frequência para esta mesma revista, o que faz deste escrito uma não excepção.

$\mathrm{O}$ texto de Kant é publicado na revista num contexto particular motivado pela ocorrência de um acontecimento recente, ainda que as suas articulações temáticas e os desenvolvimentos a que deu origem excedam o âmbito restrito do episódio que motivou a sua publicação. Pouco antes de Kant escrever o Ensaio, apareceu no final de 1763 nos arredores de Königsberg um polaco chamado Jan Pawlikowicz Zdomorzyrskich Komarnicki um homem de aspecto esfarrapado e com a atitude de um fanático religioso, que foi designado profeta das cabras, pois era com versículos bíblicos que respondia a qualquer solicitação que lhe fosse dirigida. $\mathrm{O}$ homem que se deslocava com um rebanho de ovelhas e cabras acompanhado pelo filho, tinha sofrido uma grave doença de estômago, estado a que sobreveio uma crise de perturbações alucinatórias. 
O peculiar episódio, suscitou falatório e comoção em Königsberg e foi documentado na época em vários registos, tendo também estado na origem de um artigo de Hamman, publicado na mesma revista. A esse artigo, com uma componente de quase reportagem, seguiu-se um outro, uma réplica curiosa de um anónimo, que destacava precisamente a situação do menino, filho do viandante fanatizado que o acompanhava, e cuja autoria foi atribuida por Hamman ao próprio Kant.

\section{III. Âmbito temático e outros textos com os quais mantém relação}

O episódio e o respectivo contexto continham várias possibilidades temáticas de âmbito antropológico como o são a loucura, o fanatismo e a extravagância religiosa, bem como o tema da pedagogia como porta de acesso à discussão da relação entre o estado de natureza e a vida em sociedade. A acrescentar à variedade de possibilidades temáticas há também alguns elementos que constituem a paisagem de fundo da discussão, e dão o tom ao que nela vai sendo apresentado. Entre estes contam-se, por exemplo, elementos associados ao contexto médico, saber que é o principal motivo analógico neste escrito, como o da cura e o da terapia em diversas modalidades: a dieta, a purga e a catarse. Este ambiente metafórico e expressivo marcado pela preocupação terapêutica, profiláctica e catártica, está associado ao diagnóstico e ao escopo metodológico da razão na acepção mais geral. No que respeita à expressão metafórica dominante neste período e neste texto há elementos expressivos e temáticos que parecem ser herdados da tradição médica renascentista e de Francis Bacon. A consideração dominante não é ainda a razão pura, antes o motivo da catarse e da purificação da razão, como se o que é dito das doenças da cabeça se pudesse aplicar de forma analógica à doença da razão. Assim as alusões que Kant faz à lógica e à filosofia como meios purificadores e terapêuticos, mais do que curativos, podem ser compreendidas a esta luz. Todo o ambiente metafórico emprestado pela analogia com a medicina, cria um halo purificador e moralista, o qual permite fazer a transição para o tema da influência social exercido sobre o fenómeno da doença mental e da degradação do espírito.

Não obstante, entre as possibilidades temáticas referidas, apenas algumas das que estiveram em discussão pública foram escolhidas para o excurso filosófico que Kant faz neste escrito, cujos propósitos se afastam muito do simples comentário ao episódio que lhe serviu de inspiração. São diversos os motivos que atravessam este ensaio e entre os quais há dois temas que se tornam mais importantes na respectiva composição. Ambos 
suscitavam na época um interesse fervoroso: a loucura e a influência da vida em sociedade no progresso moral do homem. No que respeita ao último tema em particular, a ideia da possibilidade de regressão a um estado de natureza não corrompido pela sociedade era um motivo de vivo interesse, pois a influência de Rosseau fazia-se sentir apaixonadamente e, como se sabe, Kant foi um seu admirador e leitor devotado. Ambas se articulavam devido a uma preocupação antropológica recente com novo ímpeto e novas feições.

No Ensaio, Kant afasta-se da consideração do fanatismo religioso e mantém os motivos rosseunianos de compreensão da formação do homem como paisagem de fundo, para tematizar o que hoje designaríamos por psicopatologia. Nele faz a apresentação de uma taxonomia do fenómeno da loucura de um ponto de vista que se aproxima do que é adoptado pela medicina e que se insere no âmbito temático da antropologia. A proximidade ao método de abordagem à medicina, justificado pela eficácia a obter no conhecimento da doença, não exclui a inovação de Kant nos planos temático e semântico. Porém, a importância real dos temas de índole social ou inspirados por Rosseau é menor do que parece à primeira impressão, pois a despeito de Kant usar a expressão, homem degenerado, ele não faz uma apologia do estado de natureza opondo-o à vida em sociedade, nem sustenta que a origem da doença mental ou das doenças do coração resida na perversão social, e chega mesmo a considerar que o homem no estado selvagem está somente protegido de algumas patologias devido à total ausência de motivos para desenvolver o seu pensamento. É um tema que atravessa o texto de o Ensaio sem, contudo, ter uma importância decisiva na determinação do apuramento do fenómeno da loucura.

O Ensaio sobre as doenças da cabeça é o único escrito de Kant que tem como tema central a loucura. Todos os outros escritos em que o assunto é apresentado e debatido são fragmentos de livros com um âmbito mais alargado, o que significa que nem todos têm a mesma relação com o tema considerado, antes o fazem a partir de diferentes pontos de vista. Todavia, esse conjunto de escritos constitui uma reflexão com comunidade temática e dá origem a um desenvolvimento filosófico com aspectos comuns, cuja articulação só pode ser feita através de uma reflexão unificadora posterior. Por consequência, a reunião desses fragmentos poderia ser a reconstituição de uma espécie de puzzle do processo kantiano de classificação e interpretação do fenómeno da loucura - vamos designá-lo deste modo para simplificar - independentemente da função que o tema desempenha na economia de cada um dos escritos. A apresentação da articulação que existe entre eles excede os nossos propósitos neste artigo, que se restringem à introdução ao Ensaio, pelo que somente os elementos relevantes para o seu esclarecimento devem ser trazidos à colação. 
A apresentação do fenómeno da loucura que Kant leva a cabo neste escrito de 1764 virá a ser uma das peças fundamentais da sua psicologia empírica, tema que se insere no âmbito disciplinar da antropologia, e que tem continuação directa na exposição da psicologia empírica e da psicopatologia no seu último livro Antropologia de um ponto de vista pragmático, de 1798. O âmbito temático próprio da exposição da loucura é o âmbito da psicopatologia, porém, o fito da investigação de Kant é o desejo de esclarecimento de uma espécie de doença da razão que se torna o motor da metafísica. É isso que começará a fazer em Sonhos de um visionário explicado pelos sonhos da metafísica e posteriormente na dialéctica transcendental da Crítica da razão pura. Os dados apurados na psicopatologia visam um esclarecimento da metafísica dogmática, sem embargo da possibilidade de figurarem num livro de psicopatologia. E se no Ensaio o carácter propulsor desse fito não é ainda claro, a articulação com os outros textos deste período revela precisamente que se trata de um dado importante para compreender o sentido desta investigação, circunstância que a comparação com a Antropologia reforça. Quando Kant escreve o Ensaio e Considerações sobre o conceito do Belo e do Sublime, nos anos de 1763-64 é do pensamento de Swedenborg que se começa a ocupar, associando-o à metafísica dogmática, o que constitui um motivo de comunidade temática entre estes dois primeiros escritos e Sonhos de um visionário. A crítica que lhe dirige tem um alcance que não é possível discutir neste momento, mas cuja validade diz respeito à metafísica na sua totalidade.

Nesta investigação, o que é mais relevante no plano filosófico é o princípio de analogia com um alcance objectivo compreensivo entre o fenómeno da loucura e o da metafísica dogmática, o que Kant procura conseguir por meio da analogia entre certas formas de loucura e alguns raciocínios da dialéctica transcendental sem chegar a constituir uma lógica da loucura intrínseca à razão, mas somente uma lógica da ilusão. A analogia com a loucura é um instrumento de construção da lógica da ilusão que constitui o cerne da dialéctica transcendental. Essa relação não é ainda clara no Ensaio, mas a despeito de ser assim, ela existe desde então na relação que se estabelece com a metafísica na preparação do texto sobre Swedenborg. Existe uma forte hipótese de que Kant tenha adoptado a classificação psicopatológica com o fito de perceber os fenómenos de excesso na metafísica, usando-a depois no comentário de outros assuntos ou acontecimentos, é o que acontece no caso de o Ensaio. O episódio referido, o profeta das cabras dá origem a um comentário sobre o tema da loucura na relação que sustenta com a vida em sociedade, criando, por exemplo, modos de compreender fenómenos distintos da loucura, como a extravagância metafísica ou religiosa. 
Por consequência, o tema da loucura não é uma simples curiosidade, mas dá expressão a uma preocupação de carácter filosófico; a razão humana tem uma inclinação intrínseca para um estado que se assemelha ao delírio, o qual conduz à construção de doutrinas e hipóteses metafísicas sem sustentação racional e com uma natureza delirante. A loucura e certas doutrinas de metafísica dogmática revelam uma relação de analogia funcional, e até mesmo uma forma de parentesco entre si. Esse é um dos temas de Os sonhos de um visionário cuja consideração influencia decisivamente a dialéctica e a doutrina transcendental do método. De forma semelhante a consideração da melancolia no escrito, Observações sobre o conceito do belo e do sublime tem que ver com a circunstância de este ser o temperamento que mais favorece a inclinação para o sublime e o cultivo da filosofia, associação que Aristóteles havia feito. A preocupação com o tema da loucura e a constituição de um campo metafórico a partir da linguagem em que se expressa não se esgota nos textos do seu primeiro período. O vocabulário que tem origem no Ensaio sobre as doenças da cabeça e nas Observações sobre o sentimento do Belo e do Sublime não desaparece, antes ressurge no pensamento futuro de Kant pelo menos em dois momentos: como um contributo para a constituição do campo semântico e metafórico que dá expressão à lógica da ilusão estruturante da dialéctica transcendental e, por outro lado, à psicopatologia do conhecimento, na Antropologia de um ponto de vista pragmático, de forma tal que ambos os aspectos se articulam. O que sucede entre os textos dos dois períodos é que se verifica uma alteração da concepção da própria loucura e também uma alteração da concepção da metafísica que cai sob a alçada deste procedimento de compreensão através da analogia.

Vamos proceder, então, a um ponto de situação da articulação entre a tematização psicopatológica no pensamento de Kant e o desenvolvimento da filosofia transcendental, repetindo e resumindo o que apresentámos neste momento. Esta relação divide-se em duas possibilidades intimamente ligadas: a primeira diz respeito à analogia entre o conteúdo das perturbações da mente e os delírios da razão, a segunda, à constituição de um campo semântico novo que forja a linguagem em que o pensamento crítico expressa as ilusões e paralogismos intrínsecos à razão. A aproximação que Kant faz entre o delírio patológico e o delírio da metafísica dogmática, num primeiro momento identificada com a de Swedenborg, é um prelúdio à consideração de uma espécie de patologia da razão, que dará origem ao diagnóstico que apresenta a razão humana como contendo em si própria elementos constitutivos ilusórios e delirantes, com uma importância tão decisiva que sem o seu concurso não haveria razão no sentido mais lato, nem razão enquanto faculdade particular, no sentido mais restrito. A petição totalizadora e sistemática que caracteriza a razão 
entendida como faculdade restrita e que conduz ao excesso e à perda de noção dos limites tem diversos elementos em comum com o delírio da loucura. A dialéctica expressa uma forma de divisão profunda da razão, a qual, segundo Kant, só pode ser resolvida com proveito pela solução a que ele próprio recorre na Crítica da Razão Pura. Isto não significa que Kant apresente uma teoria transcendental da loucura, mas outra coisa, que expressa com recurso à linguagem elaborada dezoito anos. A linguagem que é criada nestes dois primeiros escritos será retomada mais tarde na Antropologia de um ponto de vista pragmático, assim como nos cursos de antropologia, em alguns parágrafos da Crítica da faculdade de julgar e na dialéctica transcendental da Crítica da razão pura, como já afirmámos. No primeiro caso ela é retomada de forma aproximada na classificação das afecções do espírito na Antropologia, nos outros escritos surge enquanto campo expressivo de caracterização da razão pura.

No Ensaio Kant começa por apresentar uma classificação das doenças mentais, metodologia que é dominante na ciência da época, ainda que em certos detalhes destoe dos procedimento mais comuns, pois a etiologia e o princípio de organização interna da doença estão aparentemente excluídos. Essa circunstância não exclui que Kant avance numa outra direcção, excedendo a mera descrição do naipe patológico. A sua teorização inclui o esboço de uma teoria explicativa dos mecanismos de desenvolvimento do fenómeno patológico, tese que será revista na futura apresentação do tema na Antropologia. A ambivalência que acompanha o fito kantiano neste escrito oscila entre a classificação psicopatológica e o esclarecimento do delírio interpretativo, central para a compreensão futura da metafísica dogmática. O Ensaio carreia os elementos de psicopatologia que mais tarde serão transformados pela aparição do ponto de vista transcendental, o qual introduz duas alterações: transforma o sentido da classificação psicopatológica e transforma o sentido e a configuração do fenómeno da compreensão analógica da metafísica dogmática.

\section{Estudo do desenvolvimento da lógica interna do texto de o Ensaio}

No texto de as Doenças da cabeça há uma extensa variedade de apresentações de patologias concretas, um emaranhado que não raro se torna pouco claro: pouco clara a apresentação de cada uma das patologias, assim como a respectiva articulação. Vamos procurar esclarecer os aspectos mais importantes da organização deste complexo, atribuindo maior importância àqueles que dizem respeito à estrutura do texto em detrimento da consideração de cada uma das enfermidades. Kant distingue dois tipos de enfermidade: as doenças do coração e as doenças da faculdade do conhecimento. As primeiras 
são designadas perversão ou degradação da vontade (Das Verderben des Willens), enquanto as segundas são as deficiências das faculdades de conhecer (Die Gebrechen der Erkenntniskraft). As designações também se alteram na Antropologia, mas a divisão mantém-se na sua diferença fundamental. A nossa análise recai sobre as doenças do segundo tipo, por serem aquelas a que Kant atribui maior importância no seu escrito, mas também as mais relevantes para a análise que aqui estamos a fazer.

A onomástica ou taxonomia da loucura, da autoria de Kant, quer no Ensaio quer na Antropologia está alicerçada numa concepção da consciência e da faculdade de conhecer, que se organiza em torno de uma teoria das faculdades, a qual, na sua estrutura mais básica tem uma certa comunidade com a medicina da época. Este aspecto da concepção kantiana não é totalmente singular e distinto do que vigorou em outros empreendimentos teóricos da época, quer em algumas taxonomias da loucura elaboradas no âmbito do saber médico, quer pela presença de semelhante concepção do espírito humano na tradição filosófica, como sucede de forma indiscutível na filosofia moderna. A originalidade do pensamento kantiano a respeito da teoria das faculdades consiste principalmente na singularidade trazida pela concepção transcendental.

Cada uma das patologias da onomástica kantiana corresponde à perturbação de uma das faculdades humanas do conhecimento, concepção cujo desenho concreto é diferente em cada um dos dois principais escritos de Kant em que o tema é tratado. No Ensaio a consciência e o conhecimento humanos são apresentados segundo uma concepção ingénua, anterior à vigência da perspectiva transcendental, enquanto nos capítulos paralelos da Antropologia a influência da última transforma o seu próprio significado, trazendo consigo a alteração da concepção da patologia psíquica.

A concepção epistemológica ingénua de o Ensaio regula-se pela ideia de continuidade entre interior e exterior, cuja perturbação se manifesta sob a forma de descontinuidade e é introduzida pelo mecanismo de inversão (Verkehrtheit) entre percepcionado e fantasiado, de acordo com a terminologia deste escrito, o qual desaparece na Antropologia. A razão é um elemento mediador entre o interior e o exterior, estabelece os limites que traçam as fronteiras entre a vigília e o sonho, entre a realidade e a fantasia, rege o equilíbrio entre os dois planos; enquanto as paixões são as forças primitivas que movem a vontade. Nos graus mais leves da patologia há uma inversão da relação entre as paixões e a razão, de sorte que a razão deixa de dominar a paixão, produz-se então uma inversão na ordem da relação entre os elementos da percepção e da fantasia, do sonho e da vigília, que sem conduzir ao desaparecimento de nenhum deles, produz uma mudança de ascendente de um elemento sobre os restantes. Um exemplo do que foi apresentado, de uma afecção leve em que a razão se 
deixa dominar pelas paixões é a soberba, cujo alcance é mais moral do que cognitivo. Exemplo do segundo caso é o delírio (Wahnsinn), perturbação na qual há um fenómeno de adulteração do domínio da sensibilidade provocado por uma alteração da correlação de forças entre o imaginado e o percebido. A relação entre os dois pólos destes pares conceptuais, percebido e imaginado, vigília e sonho, é regida pelos princípios de continuidade e de progressividade, sendo o segundo, em parte, uma aplicação da lógica prevalecente no anterior.

A correlação de forças é pensada a partir de um mecanismo que Kant designa por inversão. A descrição e apresentação do mecanismo de inversão é feita a propósito do desarranjo (Verrücktheit), patologia em que há uma dimensão de ilusão perceptiva, pelo que chega a criar-se a aparência de que a inversão se identifica com o fenómeno de alucinação ou miragem, o que não é correcto. O mecanismo da inversão verifica-se a respeito dos vários tipos de loucura, sendo o desarranjo um exemplo privilegiado seu - aquela patologia que se poderia aproximar mais do que hoje designamos por alucinação. A inversão é o princípio que tem a pretensão de apresentar a lógica de desenvolvimento da perturbação do espírito, seja do desarranjo, seja de qualquer outra forma de patologia; é o mecanismo geral, a partir de cuja aplicação é possível classificar todos os casos particulares de perturbação, enquanto a alucinação é apenas um caso particular do mecanismo mais geral de inversão.

O mecanismo da inversão que explica a alteração do funcionamento saudável do intelecto humano aplica-se a uma situação de equilíbrio entre os diferentes elementos em conflito na concepção de Kant, por exemplo, entre o percebido e o imaginado, entre o interior e o exterior, entre as paixões e a razão. É uma concepção simples, cuja lógica resulta da ideia de que um elemento se sobrepõe aos restantes.

O exemplo mais evidente e mais simples da aplicação da inversão é o do fenómeno da alucinação na patologia que traduzimos por desarranjo. A proximidade que se verifica entre os dois mecanismos cria a aparência de a alucinação ser o modelo da inversão que origina toda a patologia. Alucinação, cujo modelo de concepção, Kant apresenta em Sonhos de um visionário de 1766. Em Sonhos de um visionário, Kant apresenta uma concepção da ilusão perceptiva ou alucinação de raíz óptica, formada a partir de um sistema de lentes, cujo modelo compreensivo tem a pretensão de explicar a percepção humana. É possível que o modelo óptico de produção da alucinação possa ter inspirado a descrição de o Ensaio, mas isso não é sustentado de forma clara, nem é decidível a partir do que fica exposto. Em todo o caso mesmo que o modelo da alucinação de raíz óptica exposto em Sonhos fosse já um adquirido no período em que Kant escreve o Ensaio, também ele não parece determinar a natureza do processo mais 
geral de organização da patologia, mecanismo de inversão. Pelo contrário, é o mecanismo de inversão que rege o funcionamento de todas as patologias incluindo a da alucinação no desarranjo.

Há uma inversão dos elementos de fantasia em relação aos elementos de realidade, de modo que a progressão do primeiro tipo de conteúdo representativo, a partir de um certo grau de intensidade, gera um excesso que conduz ao estado de doença. A inversão entre o imaginado e o percebido processa-se de uma forma tal que deixa de haver critério para distinguir um do outro, e deixando de haver distinção, o imaginado passa a ter o reconhecimento dispensado ao percepcionado, sendo, por sua vez, tomado pela realidade. Significativa é a circunstância de Kant conceber que o ingrediente de fantasia, e até mesmo conteúdos patológicos, como estando presentes e sendo constitutivos da percepção no estado saudável, diferenciando-se pela circunstância de a sua presença se verificar com menor intensidade do que no estado patológico. Trata-se de um princípio compreensivo do desenvolvimento patológico que se pode designar genealogia progressiva, de acordo com o qual os agentes patológicos são elementos constitutivos do estado saudável que sofrem um processo de intensificação da sua presença, no início imperceptível, mas que depois acaba por gerar a doença. É este fenómeno de intensificação da presença de um dos elementos constitutivos do estado saudável, habitualmente regressivo, que está na origem da patologia. É o que se passa no caso do sonho cujos conteúdos se equiparam aos do estado de vigília por deixar de haver um contraste entre ambos, circunstância em que o sujeito deixa de ter critério para diferenciar as duas dimensões e passa a confundir uma com a outra. No caso do desarranjo (Verrücktheit) verifica-se uma predominância da componente de fantasia sobre a representação perceptiva, que resulta na conversão em realidade dos representados que são do domínio da imaginação. Porém, verifica-se que esta predominância da imaginação não é um fenómeno isolado mas também uma natureza interpretativa. O passo do texto do Ensaio em que se refere a diferença entre as figuras avistadas por uma dama ou pelo seu pároco é bem um exemplo da prevalência do alcance interpretativo ou da pregnância da forma sobre a mera ilusão perceptiva, antecipando de certo modo o papel da imaginação configuradora. Nas restantes formas de patologia da taxonomia de Kant a ilusão assume a forma de um delírio interpretativo, o que é já claro no segundo tipo de patologia: o delírio (Wahnsinn). No processo de inversão que está em consideração nas outras formas de loucura o resultado da inversão não é uma percepção sem fundamento na realidade, mas uma alteração e ilusão interpretativa. 


\section{Conclusão}

Para concluir vamos fazer uma breve comparação de dois aspectos relevantes das duas versões da classificação psicopatológica separadas por trinta e quatro anos de intervalo: a do Ensaio e a da Antropologia. Tratase de uma referência simplificadora e indicativa, que apenas pretende somente alertar o leitor para possibilidades interpretativas que neste artigo não são exploradas até ao fim.

A semelhança entre as duas taxonomias é grande, porém as duas apresentam diferenças subtis e importantes. A evolução entre os dois escritos no que respeita à classificação da psicopatologia, aos princípios de compreensão e à terminologia, é o melhor meio de aferir e perceber o sentido desta compreensão de Kant. Algumas alterações da nomenclatura da loucura são fenómenos significativos para perceber a evolução do pensamento kantiano que se verifica no intervalo temporal entre os dois escritos. Por exemplo, a mudança da designação de Kopf (cabeça ou mente) para Gemüt (ânimo), o desaparecimento da referência ao mecanismo de inversão (Verkehrtheit) na Antropologia, e da importância da alucinação cujo funcionamento era fundamental no Ensaio. A sua presença como mecanismo de explicação do desenvolvimento da loucura no Ensaio, dá lugar à concepção da ocorrência de uma alteração da estrutura do funcionamento da razão. Esta mudança de perspectiva tem relação com o advento da concepção da filosofia transcendental, inspirada na ideia de que a perturbação que conduz à loucura se verifica no seio da consciência e não resulta da insuficiência da relação com a realidade exterior, o que supõe uma concepção de continuidade entre o exterior e o interior no acto de conhecimento. A influência decisiva, é precisamente o advento do ponto de vista transcendental, e a nova concepção de consciência e do processo de formação do conhecimento que a acompanha. A loucura já não resulta de uma inversão e adulteração dos dados perceptivos, mas de uma alteração no plano do entendimento.

São dois os pares conceptuais que se articulam entre si, e que podem ser fios condutores da conclusão da nossa interpretação do Ensaio, os quais têm, ao mesmo tempo, uma relação com o desenvolvimento futuro da Antropologia. Eles não são explicitados nem empregues de forma temática em nenhum dos dois casos, porém, estão presentes como compreensões orientadoras em ambos os casos e permitem clarificar a evolução que se verifica entre um texto e o outro.

Trata-se dos seguintes pares de conceitos opostos: um primeiro par em que se opõe a posição favorável à prevalência da medicina à posição que pugna pela prevalência da filosofia na compreensão e na terapêutica da doença mental; um segundo em que se verifica uma oposição entre uma 
posição somatista na qual se sustenta que a origem da doença pode residir no corpo e uma posição racionalista que sustenta que a mesma reside no excesso associado às paixões e a sentimentos exacerbados. A posição que sustenta a origem fisiológica da doença mental tem uma relação privilegiada com a prevalência do saber médico, enquanto a, última que sustenta a radicação nos conteúdos da consciência, tem relação com a predominância da filosofia como meio explicativo e de intervenção terapêutica.

No Ensaio Kant sustenta uma posição empirista, somatista e favorável à prevalência da medicina no que respeita à realização do diagnóstico e do tratamento da doença, enquanto na Antropologia sustenta uma posição racionalista e favorável à prevalência da filosofia. No primeiro a sua posição é empirista porque concebe o desenvolvimento da patologia como estando dependente de uma inversão das representações perceptivas; somatista porque concebe o corpo como estando na origem das diversas enfermidades do ânimo, em particular, as partes digestivas, o que Kant apresenta como simples hipótese a carecer de comprovação, pois a etiologia não é o fito decisivo do texto.

\section{2 - Tradução ${ }^{1}$}

\section{Ensaio sobre as doenças da cabeça}

A simplicidade e a frugalidade da natureza reclamam e constituem no homem unicamente noções comuns e uma probidade rude, enquanto o constrangimento artificial e a exuberância do estado civil geram aqui e ali tipos que são engenhosos e espertalhões, mas também intrujões e tolos, assim como origina a aparência sensata ou decente, a qual pode dispensar o entendimento e a rectidão, sempre que o formoso véu que o decoro estende sobre as deficiências ocultas da cabeça e do coração estiver tecido com suficiente espessura. À medida que a arte [Kunst] se eleva, a razão e a virtude tornam-se finalmente o mote, mas de sorte que o zelo de falar de ambas pode dispensar pessoas instruídas e bem-educadas de se

\footnotetext{
${ }^{1}$ Apresentamos a tradução de o Ensaio sobre as doenças da cabeça realizada a partir da $1^{\text {a }}$ edição de Kants Werke, por Wilhelm Weischeidel, Darmstadt, Wissenschaftliche Buchgesellschaft, 1983. Band II, Vorkritische Schriften bis 1768. Como sucede na tradução dos escritos de Kant que tenham a pretensão de rigor, procedeu-se a uma comparação com o texto da edição da Academia das Ciências da Prússia, Kants Gesammelte Schriften, Berlin, 1912, volume II. Tradução Edições 70 ○. O tradutor agradece à editora a autorização para esta publicação.
} 
incomodar com a sua posse. $\mathrm{O}$ apreço geral dispensado às duas louváveis qualidades torna digno de nota, no entanto, a diferença que reside na circunstância de que todas as pessoas anseiam muito mais pelas vantagens do entendimento do que pelas boas qualidades da vontade, e que, na comparação entre a estupidez e a malícia, toda a gente se pronuncia sem hesitar um só momento em favor da última. Isto é sem dúvida muito bem pensado, pois, se tudo passa a depender da arte, não se pode dispensar a astúcia refinada em tais relações, ao contrário do que se passa com a probidade, que numa tal situação se torna apenas um empecilho. Eu vivo entre cidadãos sábios e de bons costumes, ou seja entre aqueles que sabem aparentá-lo, e confio que se tenha a correcção de me conceder um tal grau de subtileza, que mesmo que estivesse na posse dos remédios mais fiáveis para lhes arrancar as doenças da cabeça e do coração, eu, apesar de tudo, teria escrúpulos em trazer à praça pública, essa tralha antiquada. Sei muito bem que a cura do entendimento e do coração apreciada pela moda já está na senda do progresso desejável e que, sobretudo os médicos do primeiro, que se designam lógicos, satisfazem a exigência geral a seu respeito, desde que fizeram a importante descoberta de que a mente humana, no fundo, é um tambor que só ressoa porque é oco. Não vejo nada melhor do que imitar o método dos médicos, que acreditam terem sido muito úteis aos doentes quando dão um nome à sua doença, e esboçarei uma pequena onomástica das deficiências da cabeça; a começar pela paralisia que ocorre na imbecilidade (Dummkopf), chegando às convulsões na loucura furiosa; no entanto, para mostrar a génese gradual destas doenças repugnantes considero que é necessário elucidar os graus mais leves, desde a idiotia à estultícia porque estas são as mais comuns nas relações existentes no estado civil, que, no entanto, conduzem às primeiras, as mais repugnantes.

O obtuso (Stumpfkopf) carece de engenho (Witz), o imbecil de entendimento. A agilidade para conceber alguma coisa e ser capaz de se lembrar disso, bem como a facilidade para o expressar apropriadamente depende muito do engenho. Daí que aquele que não é imbecil, pode, apesar de tudo, ser muito obtuso, porque dificilmente lhe entra alguma coisa na cabeça, ainda que o venha a entender mais tarde devido a um progresso na maturação do juízo, enquanto a dificuldade de expressar-se nada prova a respeito da capacidade de entender, apenas mostra que o espírito não contribui o suficiente para vestir o pensamento com as diferentes expressões que lhe assentam com mais acerto.

O famoso jesuíta Clavius foi corrido da escola, tido como incapaz, (pois segundo a concepção de inteligência de Orbile um rapaz não tem préstimo para mais nada se não sabe fazer versos nem os exercícios escolares de retórica); mais tarde descobriu por acaso a matemática, e 
então o jogo inverteu-se, e os seus antigos professores não passavam de néscios ao pé dele.

O juízo prático dos homens sobre os seus afazeres, como o exige o lavrador, o artesão e o marinheiro etc, é muito diferente daquele de que se servem no trato entre si. Este último não é tanto entendimento como esperteza, e à falta amável desta tão prezada capacidade chamamos simplicidade. Se procurarmos a causa desta na fraqueza da faculdade de julgar em geral, podemos designar um tal homem por simplório ou por pateta.

Uma vez que as intrigas e os falsos artifícios se transformam gradualmente, na sociedade civil, em máximas de uso habitual e o jogo da acções humanas acaba por se complicar, não é por isso de admirar que um homem que por natureza é sensato e íntegro, para quem toda esta esperteza é demasiado desprezível para dela se ocupar, ou que não pode levar o seu coração honesto e benevolente a formar um conceito tão odioso da natureza humana; não admira então que um tal homem possa cair por toda a parte nas armadilhas de intrujões, e tenha de ser um motivo de paródia para eles, de maneira que a expressão um homem bom acaba por não significar literalmente um simplório; às vezes significa também um c....; pois na linguagem dos malandros só é um homem sensato aquele para quem todos os outros não são nada melhor do que ele próprio, a saber, um intrujão.

Os impulsos da natureza humana chamam-se paixões quando têm uma grande intensidade, nesse caso são as forças motrizes da vontade; o entendimento só intervém para avaliar a soma total da satisfação de todas as inclinações, a partir das finalidades representadas, e para encontrar os meios necessários para as concretizar.

Quando, por exemplo, uma paixão é especialmente poderosa, então o entendimento pouco consegue contra ela; pois a pessoa enfeitiçada não deixa de ver as razões contrárias à sua inclinação preferida, só que se sente impotente para as pôr em prática. Quando esta inclinação é boa em si e, se além disso a pessoa é sensata, sucede apenas que a inclinação prevalecente trava o desfecho que parece inevitável por ter em conta as consequências nefastas, então a este estado da razão agrilhoada chama-se insensatez. (Torheit).

Um insensato pode ter um grande entendimento, mesmo no juízo sobre aquelas suas acções em que se revela insensato, e até tem de ter um grande entendimento e um bom coração para merecer a designação atenuante para os seus excessos. O insensato pode dar, quando muito, um excelente conselheiro para os outros, a despeito de o seu conselho não ter qualquer efeito nele próprio. Só é capaz de criar juízo quando sofre certos prejuízos ou então devido à idade, circunstância essa que, no entanto, muitas vezes só afasta uma loucura para dar lugar a outra. Desde que o mundo é mundo 
que a paixão amorosa, ou um grau elevado de ambição, transformaram muito boa gente sensata em insensata. Uma moça obrigou o temível Alcides a fiar na roca e os cidadãos ociosos de Atenas enviaram Alexandre até ao fim do mundo devido a um louvor ridículo. Há também inclinações menos intensas e frequentes que, não obstante, não deixam de gerar o seu tipo de insensatez, por exemplo, a mania das construções, a paixão pela arte e a bibliofilia.

O homem degenerado abandonou o seu lugar natural e é atraído e retido por tudo o que lhe aparece. O homem avisado opõe-se ao insensato, no entanto, aquele que não for insensato é um sábio. Este sábio pode, eventualmente, ser procurado na lua, sítio onde talvez o homem seja desprovido de paixão e tenha um entendimento infinito. Graças à sua imbecilidade o apático está a salvo da insensatez, porém, ao olhar comum tem o semblante de um sábio. Num barco, onde, durante uma tempestade todos estavam amedrontados, Pirro viu um porco comer calmamente da sua gamela e disse apontando-o: "assim deve ser a serenidade de um sábio". O apático é o sábio de Pirro.

Quando a paixão dominante é em si própria odiosa e ao mesmo tempo suficientemente repelente, para se considerar que a satisfação da mesma é oposta ao desígnio da sua natureza, então este estado em que a razão está invertida é designado estultícia (Narrheit). O insensato (Tor) compreende muito bem o verdadeiro fito da sua paixão quando lhe concede um poder capaz de manter a razão agrilhoada. Porém, o estulto fica, ao mesmo tempo, num estado de tal estupidez que só crê estar na posse de algo quando se priva daquilo que deseja. Pirro sabia perfeitamente que a valentia e o poder conquistam a admiração geral. Ele seguia os impulsos da ambição e não era senão o que Cineas tinha sustentado a seu respeito: um insensato. No entanto, quando Nero se expõe ao escárnio público, recitando do alto de uma tribuna uns versecos para ganhar o prémio de poesia e ao dizer já no fim da vida: quantus artifex morior (que grande artista morre comigo) ${ }^{2}$; só posso ver neste temido e escarnecido tirano de Roma um estulto. Considero que toda a estultícia tem origem em duas paixões: a soberba e a avareza. Ambas as inclinações são injustas e por isso detestadas; ambas são pela sua própria natureza repelentes, e a sua finalidade destrói-as a si próprias. O soberbo ostenta uma pretensão aberta de superioridade sobre as outras pessoas, através de um desdém explícito por elas. Acredita ser honrado quando está a ser vaiado, pois é evidente que o desprezo pelos outros espicaça neles a sua própria vaidade, voltandose contra o arrogante. $\mathrm{O}$ avarento, se lhe dermos crédito, precisa de muitas

\footnotetext{
${ }^{2}$ Nota do Tradutor.
} 
coisas e de modo algum pode prescindir do menor dos seus bens, todavia acaba por prescindir de todos pois devido à mesquinhez faz deles coisa sua sem desfrute. A cegueira (Verblendung) própria da soberba gera tolos, em parte enfatuados, em parte patetas, conforme tenha sido, ou uma volubilidade ridícula, ou uma estupidez rígida, a tomar conta da sua cabeça oca. A cupidez vil desde sempre deu azo a muitas histórias risíveis, de tal modo que dificilmente a fantasia as poderia inventar mais extraordinárias do que são na realidade. O insensato não é sábio, e o estulto (Narr) não é inteligente. $\mathrm{O}$ escárnio que o insensato chama sobre si próprio é divertido e inofensivo, o estulto merece a flagelação mais mordaz do sátiro, ainda que a não sinta. Não devemos desesperar totalmente da possibilidade de um insensato se vir a tornar sensato algum dia, mas quem tenciona tornar inteligente um estulto é como quem lava um negro. A causa disso é que no primeiro reina, apesar de tudo, uma inclinação verdadeira e natural que, quando muito, agrilhoa a razão a uma certa situação, ao passo que no segundo uma quimera tola inverte os princípios da razão. Deixo aos outros o cuidado de descobrir se há motivo para ficar preocupado com a profecia bizarra de Holberg, a saber que o aumento quotidiano de estultos é grave, e leva a recear que eles venham a meter na cabeça a fundação da Quinta Monarquia. Admitamos, portanto, que tenham este propósito, ainda assim eles não deveriam ter tanto zelo, pois um poderia sussurrar com toda a razão aos outros, aquilo que o conhecido bobo de uma corte vizinha quando vestido de arlequim atravessou a cavalo uma cidade polaca, proclamando aos estudantes que o seguiam - "Meus senhores aplicai-vos, aprendei a fazer alguma coisa, pois se formos demasiado numerosos não haverá sustento para todos".

Vou passar das deficiências da cabeça que são desprezadas e escarnecidas para aquelas que habitualmente são vistas com comiseração; das que não suprimem a sociedade civil livre para as que caem sob a alçada das autoridades, que são levadas por isso a tomar as disposições necessárias. Divido estas doenças em dois tipos: o primeiro é a impotência, o segundo é a inversão (Verkehrtheit). As primeiras caem sob o título geral de idiotia, as segundas sob o de ânimo perturbado. O idiota encontra-se numa grande impotência da memória, do entendimento e geralmente também das sensações. Este mal é, na maior parte dos casos, incurável, pois se a supressão do caos do cérebro perturbado já é difícil de suprimir, deve ser quase impossível insuflar uma vida nova nos seus orgãos que deixaram de funcionar. As manifestações desta fraqueza que nunca permitem aos infelizes que dela padecem sair da condição infantil, são por demais conhecidas pelo que não é necessário alongar-me mais a seu respeito.

As deficiências da cabeça perturbada dividem-se numa multiplicidade de categorias tão numerosas quanto as faculdades do ânimo por elas 
atacadas. Julgo que podem ser ordenadas segundo as três divisões seguintes: primeiro, a inversão dos conceitos empíricos no desarranjo (Verrückung); segundo, a faculdade de julgar posta em desordem por esta experiência empírica, no delírio (Wahnsinn); terceiro, a insânia (Wahnwitz) em que a razão é invertida no que concerne a juízos mais universais. Todas as demais manifestações do cérebro doente podem ser entendidas, no meu parecer, quer como graus diferentes dos estados referidos, quer como uma infeliz combinação destes males entre si, ou ainda como resultado do enxerto em paixões fortes, de maneira que as podemos subordinar à classificação anterior.

No que diz respeito ao primeiro mal, a saber, o desarranjo (Verrückung), passo a explicar as suas manifestações do modo seguinte: a alma de toda e qualquer pessoa, mesmo no seu estado completamente saudável, está sempre ocupada a pintar imagens de coisas que não estão presentes ou a completar as semelhanças imperfeitas entre as coisas presentes na representação, através de um ou outro traço quimérico que a nossa faculdade poética criadora (schöpferische Dichtungsfähigkeit) inscreve na representação sensível. Não temos motivos para acreditar que no estado de vigília o nosso espírito seja regido por leis diferentes das que vigoram durante o sono, pelo contrário, pode supor-se, que no primeiro caso, o da vigília, somente a vivacidade das impressões sensíveis obscurece e torna irreconhecíveis as difusas imagens quiméricas, em vez de supor que estas últimas têm toda a sua intensidade durante o sono, quando o acesso da alma está vedado a todas as sensações exteriores. Não é por isso de admirar que os sonhos, enquanto durarem, sejam tomados por experiências verdadeiras de coisas reais. Pois, por serem nesse estado as representações mais fortes na alma, são o equivalente das sensações no estado de vigília. Supondo que certas quimeras, seja qual for a sua causa, tenham como que afectado um qualquer orgão do cérebro, de modo que a impressão causada seria tão profunda e simultaneamente tão efectiva como uma sensação é capaz de ser, então esta fantasia (Hirngespinst) teria de ser tomada por uma experiência real, mesmo no estado de vigília e encontrando-se a pessoa na posse de uma boa e saudável razão. Pois seria inútil opor justificações racionais a uma representação sensível ou a uma representação com intensidade semelhante, porque os sentidos inculcam-nos, a respeito das coisas reais, uma convicção muito superior a qualquer raciocínio; pelo menos aquele que está enfeitiçado por esta quimera nunca poderá ser levado, simplesmente pela via racional, a duvidar da realidade da sua pretensa sensação. Também se dá o caso de pessoas que em outras ocasiões revelam suficiente razão madura, afirmarem resolutamente, contudo, ter visto com toda a atenção, vá-se lá saber que formas fantasmagóricas e carantonhas, e que são tão sagazes que estabelecem uma correlação entre 
a experiência imaginada e um certo juízo subtil da razão. Chama-se desarranjo a esta condição da pessoa perturbada segundo a qual está habituada a representar, no estado de vigília, sem um grau de doença particularmente acentuado certas coisas, ausentes, como sendo claramente sentidas. Quem sofre de desarranjo é alguém que sonha acordado. Se a miragem (Blendwerk) habitual dos seus sentidos for apenas parcialmente uma quimera, na maior parte, porém, uma sensação verdadeira, aquele que sofre num grau mais elevado dessa inversão é um lunático (Phantast). Quando depois do despertar, divagamos numa distracção descontraída e suave, a nossa imaginação transforma em figuras humanas, formas irregulares do dossel da cama, ou certas manchas de uma parede mais próxima, com um aparente rigor que nos distrai de forma bastante agradável, de sorte que podemos decidir o momento em que dissipamos essa miragem. Por conseguinte sonhamos só em parte e podemos dominar a quimera. Se acontecer alguma coisa parecida com esta num grau mais elevado, sem que a atenção do acordado consiga arredar a miragem da representação enganadora, podemos supor neste estado de inversão tratarse de um lunático. Este acto de se iludir a si próprio no que concerne às sensações, é, de resto, muito comum, e enquanto não for grave é poupado a esta designação, ainda que, quando se lhe acrescenta uma paixão, esta fraqueza de ânimo se agudize e degenere numa efectiva fantasmagoria. Aliás, as pessoas, devido a uma cegueira (Verblendung) comum, não vêem as coisas como são, mas como a sua inclinação as pinta diante dos olhos; o naturalista vê cidades na florencite, o devoto vê nos veios do mármore a narração da paixão de Cristo, certa dama através da luneta vê na lua a sombra de dois amantes ao passo que o seu padre vê dois campanários $\mathrm{O}$ pavor transforma os raios da aurora boreal em lanças e gládios, e, ao crepúsculo, um poste de indicação de caminho num fantasma gigante.

A predisposição do ânimo para a fantasia em nenhum caso é tão comum como na hipocondria. As quimeras que esta doença gera, não iludem, no fundo, os sentidos externos, criam somente uma miragem do sentimento do seu próprio estado, seja do corpo seja da alma, o que na maior parte dos casos não passa de uma cisma. O hipocondríaco sofre de um mal que seja qual for a sua sede principal, provavelmente percorre irrequieto o tecido nervoso das várias partes do corpo. Este mal, no entanto, cobre com vapores melancólicos a sede da alma, de maneira que o paciente sente em si próprio a alucinação de todas as doenças de que ouvir falar. Aquilo de que gosta mais de conversar é do seu mal-estar, gosta de ler livros de medicina, e encontra por todo o lado casos com um padecimento semelhante ao seu. No convívio social tem acessos de boa disposição sem dar por isso, ri muito, come bem, aparenta ser habitualmente um homem saudável. A respeito da sua fantasmagoria 
interior as imagens que se formam no seu cérebro têm frequentemente uma intensidade e duração que se lhe tornam penosas. Quando lhe aparece uma figura caricata na mente (mesmo que ele próprio a reconheça apenas como uma fantasia) e quando esta cisma lhe arranca um riso inconveniente na presença de outras pessoas sem que lhes mostre o motivo, ou quando algumas representações obscuras despertam nele um impulso violento que o leva a fazer algo de mal cuja irrupção o amedronta e angustia, ainda que não chegue nunca a concretizá-lo, então estes estados de alma têm grande semelhança com os daquele que sofre de desarranjo, ainda que não inspirem cuidado. O mal não está enraizado profundamente, e na medida em que diz respeito ao ânimo (Gemüt), é facilmente suprimido, quer espontaneamente, quer por meio de remédios.

Uma mesma representação actua sobre a sensação com graus de intensidade muito diferentes, conforme os diversos estados do ânimo de uma pessoa. Há, portanto, um certo tipo de actividade fantasiadora que é atribuída a alguém unicamente porque o grau de intensidade do sentimento por meio do qual é afectado por certos objectos excede a medida aceitável para uma mente saudável. Deste ponto de vista o melancólico é um lunático a respeito dos males da vida. $\mathrm{O}$ amor tem em abundância encantamentos maravilhosos, e a mais refinada arte dos estados antigos consistia precisamente em tornar os seus cidadãos visionários (Phantasten) do bem-estar público. Quem, se sentir mais exaltado por um sentimento moral do que por um princípio ou axioma, mais do que outros possam imaginar de acordo com o seu sentimento frouxo e muitas vezes pouco nobre, é tido por estes como um visionário exaltado. Eu coloco Aristides entre os agiotas, Epicteto entre os cortesãos e Jean Jacques Rosseau entre os doutores da Sorbonne. Parece-me que ouço uma gargalhada sonora de escárnio e cem vozes clamam: que lunáticos! Esta aparência ambígua de devaneio fantasioso a respeito de sentimentos que em si próprios são moralmente bons, é o entusiasmo, e sem ele nada de grande foi alguma vez alcançado neste mundo. Algo completamente diferente se passa a respeito do fanático (arrebatado, exaltado). Este é, no fundo, um louco que se atribui uma inspiração imediata e uma intimidade com os poderes do céu. A natureza humana não conhece miragem mais perigosa. Quando o surgimento for recente, o iludido tiver talentos e a enorme turba estiver preparada para receber o fermento com sofreguidão, então às vezes até o estado acaba por sofrer convulsões. A exaltação conduz o inspirado ao extremo: Maomet ao trono do príncipe, João de Leiden ao cadafalso. Posso contar ainda entre as formas de perturbação da mente a perturbação da memória, na medida em que, perturba os conceitos empíricos. Pois esta perturbação ilude os desgraçados afectados por este mal através de uma representação quimérica, sabe-se lá de que estado passado, que na verdade 
nunca existiu. Aquele que fala de bens que diz ter possuído antigamente, ou de um reino em que outrora reinou, e que não se ilude de maneira assinalável quanto ao seu estado actual, é um alucinado a respeito da memória. $\mathrm{O}$ velho rabugento que acredita firmemente que na sua juventude o mundo e os homens foram melhores é um lunático relativamente à memória.

Até aqui a perturbação da mente, no fundo, não atacou a faculdade de entendimento, pelo menos não é necessário que isso tenha acontecido, pois o erro reside apenas nos conceitos, e se quisermos tomar as sensações erradas como verdadeiras, os juízos podem ser correctos e até mesmo invulgarmente racionais. Uma perturbação do entendimento, pelo contrário, consiste na produção de juízos de experiência de forma invertida e o primeiro grau desta doença, o delírio (Wahsinn), atenta contra as regras gerais do entendimento mesmo nos juízos mais próximos da experiência. O delirante vê e lembra-se dos objectos com a mesma correcção que qualquer pessoa saudável, simplesmente interpreta o comportamento dos outros como estando relacionado consigo próprio, devido a uma disparatada ilusão, e acredita poder ler neste, sabe-se lá que desígnios alarmantes de que estas pessoas nunca se lembrariam. Quem o ouvir poderia acreditar que toda a cidade se ocupa dele. Os mercadores que vendem no mercado, se por acaso o olham congeminam de alguma forma um atentado contra ele: o guarda-nocturno chama-o só para dele troçar, e, resumindo, por todo o lado vê apenas uma conjura contra si. O melancólico que é delirante devido às suas suposições tristes ou ultrajantes é um macambúzio. Contudo, há também delírios deleitosos e a paixão amorosa lisonjeia-se ou aflige-se com as interpretações mais variadas e espantosas que se assemelham ao delírio. Um soberbo é de certo modo um delirante que conclui com escárnio da conduta dos que o fitam que o estão a admirar. $\mathrm{O}$ segundo grau da perturbação da mente a respeito da faculdade superior de conhecimento é, no fundo, a razão posta em desordem, enquanto se perde de um modo disparatado em juízos finamente construídos sobre conceitos gerais, e pode ser designada por insânia (Wahnwitz). No grau superior dessa perturbação contam-se inumeráveis intuições subtis que se enxameiam no cérebro em ebulição: o comprimento dos mares, a decifração de certas profecias, e sabe-se lá que mistura de quebra-cabeças fúteis.

Quando o infeliz perdeu simultaneamente a capacidade de formular juízos sobre a experiência, então chama-se vesânico (Aberwitzig). No caso porém, em que se baseia num grande número de juízos de experiência correctos, simplesmente a sua sensibilidade seja extasiada pela novidade e pelo cortejo de efeitos que o seu espírito lhe apresenta, de sorte que deixa de atentar na correcção da respectiva articulação coerente, produz-se então a partir dali uma forma brilhante de insânia, um desvario que pode 
coexistir com um grande génio, visto que a razão na sua lentidão já não consegue acompanhar o espírito revolto.

$\mathrm{O}$ estado de perturbação da mente que consiste na incapacidade de receber sensações externas é o estado desprovido de sentido; este então, na medida em que é dominado pela cólera, chama-se frenesi. O desespero é uma perturbação passageira de alguém que perdeu a esperança. A veemência impetuosa de um perturbado chama-se de um modo geral delírio furioso. O frenético, na medida em que está desprovido de sensibilidade, é um louco furioso.

O homem que se encontra no estado natural só pode suportar um pouco de insensatez e dificilmente alguma estultícia. As suas necessidades mantêm-no constantemente próximo da experiência e dão ao seu entendimento saudável uma ocupação tão leve que ele mal repara que necessita da razão para dirigir as suas acções. Aos seus apetites rudes e vulgares dá a inércia uma moderação, que deixa poder suficiente à pouca faculdade de julgar, de que necessita para os dominar com a máxima vantagem para si próprio. Onde iria ele buscar a matéria para a estultícia, uma vez que não precisa de se preocupar com o juízo dos outros nem pode ser vaidoso ou enfatuado? Dado que não tem qualquer representação do valor dos bens não desfrutados está a salvo do absurdo da cupidez, e porque nenhum rasgo espirituoso (Witzig) entra na sua cabeça está também acautelado contra qualquer tipo de insânia. Da mesma forma a perturbação do ânimo raramente tem lugar neste estado de simplicidade. Se o cérebro do selvagem tivesse recebido algum impulso do exterior, não sei de onde proviria a fantasmagoria para reprimir as sensações habituais que o ocupam de modo constante e em exclusivo.

Que delírio poderia dar-lhe na cabeça, dado que nunca tem motivo para se aventurar muito longe no seu juízo. Já a ocorrência da insânia (Wahnwitz) excede certamente de todo em todo a sua capacidade. Quando tiver uma doença da cabeça transformar-se-á então num imbecil ou num insensato, ainda que muito raramente isso venha a acontecer, pois na maior parte das vezes, ele é saudável por ser livre e por poder mover-se à sua vontade. É no estado civil que, no fundo se encontra o fermento de todas estas deteriorações, que, ainda que as não produza, serve para as alimentar e aumentar. $\mathrm{O}$ entendimento, na medida em que satisfaz as necessidades e os prazeres simples da vida, é um entendimento sensato, contudo, quando solicitado para a opulência artificiosa, seja nos prazeres, seja nas ciências, torna-se um entendimento refinado. $\mathrm{O}$ entendimento sensato do cidadão seria, portanto, em comparação com o homem próximo do estado natural, um entendimento refinado, e os conceitos que em certas classes pressupõem um entendimento subtil, já não convêm àqueles que, pelo menos no que toca à compreensão imediata, estão mais próximos da simplicidade da 
natureza, tornando-os normalmente estultos quando dela fazem uso.

$\mathrm{O}$ abade Terrasson distingue em algum passo entre os que têm o espírito perturbado, aqueles que deduzem representações correctas a partir de representações falsas, dos que, de representações correctas deduzem de forma completamente incorrecta. Esta divisão está perfeitamente de acordo com as ideias que aqui temos apresentado. Entre os do primeiro tipo, contam-se os lunáticos, ou alucinados cujo entendimento, no fundo, não sofre, o que sucede somente com a faculdade que na alma desperta os conceitos de que a faculdade de julgar se serve mais tarde para os comparar.

Pode-se muito bem contrapor juízos racionais a esses doentes, ainda que não seja para suprimir o seu mal, mas, pelo menos, para o diminuir. Visto que naqueles que pertencem ao segundo caso, os delirantes e os insanos, o próprio entendimento está atacado, não só é insensato raciocinar com eles, mas também muito nocivo (não seriam delirantes se fossem capazes de apreender estes motivos racionais). Assim dá-se às suas mentes invertidas novos motivos para produzir disparates; a contradição não os melhora, só os excita, e é indispensável que se tenha no trato com eles uma atitude impassível e benevolente, como se não se desse conta, de que há alguma coisa errada no seu entendimento.

Designei as deficiências da faculdade de conhecer, doenças da cabeça, enquanto é costume chamar à deterioração da vontade, uma doença do coração. Também só cuidei destas manifestações no ânimo sem querer descobrir as suas raízes que presumivelmente residem no corpo, e que têm, nomeadamente, a sua sede principal mais nas partes digestivas do que no cérebro, tal como o popular semanário geralmente conhecido pelo nome de o Médico, de modo convincente o sustenta nos números 150, 151, e 152. Não me posso de maneira nenhuma convencer que a perturbação do ânimo derive da soberba, do amor, de cogitações muito intensas, e sabese lá de que mau uso das forças da alma, como habitualmente se pensa. Este juízo, que faz do doente e da sua infelicidade um motivo de reprovação sarcástica, é muito cruel e baseia-se num erro comum, segundo o qual se costuma confundir causa e efeito. Quando se atenta um pouco nos exemplos, reconhece-se que sofre primeiro o corpo; que no início quando o germe da doença se desenvolve imperceptivelmente, se sente uma inversão ambígua da mente que não encerra a suspeita de uma perturbação do ânimo, que se expressa em caprichos amorosos profundos, numa atitude enfatuada e por último num matutar profundo e estéril. Com o tempo a doença manifesta-se e leva a crer que a sua razão reside no estado do ânimo que a precedeu. Deveria dizer-se antes, que a pessoa se tornou soberba, porque já estava perturbada num certo grau, em vez de dizer que ficou perturbada, porque era soberba. Esses tristes males, se não forem 
simplesmente hereditários, permitem sempre esperar uma recuperação bem sucedida, e aquele cuja assistência aqui se deve privilegiar é o médico. No entanto, não quero, por uma questão de honra, excluir o filósofo, que pode prescrever a dieta do ânimo, apenas na condição de que, tal como na maior parte das suas ocupações, não exija pagamento. Em recompensa o médico também não recusaria prestar auxílio ao filósofo, se este procurasse experimentar o grande tratamento para a estultícia, que acabou sempre malogrado. Por exemplo, ele poderia tomar em consideração no frenesi de um agitador instruído, se meios catárticos tomados numa dose maior teriam algum efeito contra esse tipo de acesso. Pois, de acordo com as observações de Swift, um mau poema não é senão uma purificação do cérebro, através da qual são eliminados muitos humores nocivos para alívio do poeta doente; por que razão um escrito miserável e cismático não poderia ser a mesma coisa? Neste caso seria, no entanto, aconselhável indicar à natureza uma outra via de purificação, para que o mal possa ser arrancado de uma vez para sempre e em privacidade sem perturbar, com isso, a comunidade. 